\title{
Acquisitions, Joint Ventures or Arm's-Length Alliances? Analyzing the Determinants of the Choice of Growth Strategy in Brazil from 1996 through 2007
}

\author{
E duardo Kazuo Kayo* \\ E-mail address: kayo@usp.br \\ Universidade de São Paulo - FEA/USP \\ São Paulo, SP, B razil.

\section{Herbert Kimura} \\ E-mail address: hkimura@ mackenzie.br \\ Universidade Presbiteriana M ackenzie \\ São Paulo, SP, B razil.
}

\section{Mauricio R éa Patrocínio}

E-mail address: mauricio.rea@uol.com.br Universidade Presbiteriana M ackenzie São Paulo, SP, B razil.

\section{L uis E lesbão de Oliveira Neto}

E-mail address: elesbao@cflex.com.br Universidade Presbiteriana M ackenzie São Paulo, SP, Brazil.

\begin{abstract}
This paper analyses the determinants of the choice among different firm growth strategies: acquisitions, joint ventures or arm's-length alliances. Several theoretical perspectives offer a background to understanding how firms make this choice. However, most empirical studies in this field have been derived from firms in developed countries. In contrast, we turn our attention to the analysis of the growth process of firms in a particular developing country, B razil. The results mostly support the learning perspective of the firm's choice. In general, a firm's previous experience in a specific strategy (e.g.: joint ventures) is significant to determine its future choice for the same strategy as a path to grow. Extending previous studies, we introduced some financial factors as explanatory variables but they showed no statistical significance.
\end{abstract}

Key words: acquisition; joint venture; strategic alliance; growth strategy; governance mode.

Received 14 M ay 2009; received in revised form 25 M ay 2010.

Copyright (c) 2010 B razilian A dministration Review. All rights reserved, including rights for translation. Parts of this work may be quoted without prior knowledge on the condition that the source is identified.

\footnotetext{
* Corresponding author: Eduardo K azuo K ayo

Faculdade de Economia, Administração e Contabilidade, Av. Prof. Luciano Gualberto, 908, São Paulo, SP, 05508-010, B razil.
} 


\section{INTRODUCTION}

One important issue in strategy is to understand the sources of performance heterogeneity among firms. In other words, a great deal of studies in this field seeks to analyze variables that make a firm show abnormal performance in relation to their competitors. As Peteraf (1993) suggests, this heterogeneity is largely determined by the firm's internal resources and capabilities. Thus, access to these resources and capabilities may allow firms to generate abnormal returns and build important competitive advantages. Obtaining these resources can take place in several ways. Makadok (2001) states that firms have the option to grow internally through the process of capability-building, or externally through resource-picking. In addition, external growth embeds specific options such as mergers, acquisitions, joint ventures or other kinds of alliances. Whichever is the growth option, this decision should take into account the uniqueness of the firms and the potential of value creation of each alternative.

Studies on strategic alliances - including mergers, acquisitions, joint ventures and other kind of alliances - can follow at least two different research streams. One of these streams analyses the impact of strategic alliances on a firm's value creation (i.e., cumulative abnormal returns or CAR). In general, recent studies in this line of inquiry show that firms' alliances have the potential to create value for their shareholders. A second stream of studies analyzes what determines the choice for a specific strategy, i.e., which factors drive firms' decisions among different sorts of governance mode. Our article examines this latter issue.

The objective of this article is to analyze the determinants of choice among different strategies of a firm's external growth: acquisitions, joint ventures or arm's-length alliances. As a consequence, we expect to offer two main contributions. First, to our knowledge there are no previous studies that analyze those determinants in the Brazilian context. Some studies (Brito, Batistella, \& Famá, 2005; Camargos \& Barbosa, 2007; Patrocínio, Kayo, \& K imura, 2007, among others) that analyzed value creation in a given strategic alliance event have already been done in B razil. However, works that analyze the determinants of the choice among those different types of alliances are still in their infancy. Second, extending the list of usual determinants, we include two financial variables leverage and systematic risk. Likewise, to date we have not found any studies that took these factors into account. In addition, we analyze the role of a firm's intangibility, experience in joint ventures, experience in acquisitions and relatedness between focal and target/partner firms in determining the growth option.

The results show a significant influence of the accumulated experience by repeating the same strategy. For instance, the greater the experience in acquisitions, the greater the likelihood that firms promote another acquisition as an option to grow. Moreover, we found that greater relatedness between firms leads them to choose more aggregated modes of governance (e.g., acquisition instead of joint ventures). Financial variables did not show statistical significance in explaining growth strategy, but we believe that improvements in the construction of these variables can provide better results in future studies.

\section{THEORY AND HYPOTHESES}

\section{The Growth of the Firm and the Role of Strategic Alliances}

Penrose (1959) suggests two possible growth paths for a firm: (1) to "build new plants and to create new markets for itself" (p. 156) or (2) to "acquire plants and markets of al ready existing firms" ( $p$. 156). Simply stated, the first option can be defined as internal growth and the second, as external growth. M oreover, external growth is not limited to mergers or acquisitions, but can be extended to 
other kinds of alliances. In general terms, we follow Teece (1992) to define strategic alliances as a process in which two or more partners share the commitment of reaching a common objective, combining their resources and capabilities in coordinated activities, which may or not involve stock sharing. Specifically, strategic alliances may be classified in a continuous scale of different governance modes with the market at one extreme and the hierarchy at the other. B etween these two extremes resides what Williamson (1991) calls hybrid forms of economic organization - which include joint ventures, arm's-length contracts, etc. Indeed, Hennart (1993) suggests that hybrid forms are more common than the most extreme forms.

Our paper particularly focuses on three forms of strategic alliances: acquisitions, joint ventures and arm's-length alliances. This later alliance could also be defined as "contractual alliances" (Das, Sen, \& Sengupta, 1998, p. 28), which are less formal and demand less commitment because they do not involve the formation of a new company, as is the case of joint ventures. A joint venture in its turn "occurs when two or more firms pool a portion of their resources within a common legal organization" (K ogut, 1988, p. 319). The main difference between joint ventures and mergers and acquisitions is that the latter involves a combination of the totality - and not just a part - of the resources (Sawler, 2005), allowing the partners to continue to make independent decisions especially in other business units not related to a specific joint venture contract. Furthermore, according to Sawler (2005), mergers and acquisitions tend to be permanent while alliances are typically of limited duration. Finally, also according to Sawler (2005), mergers and acquisitions eliminate the competition among the parties involved, while alliances allow the counterparts to continue competing amongst themselves in other business segments.

Several studies show evidence of value creation regarding the different forms of governance. For instance, Uhlenbruck, Hitt and Semadeni (2006), and Capron and Pistre (2002) show that, because of valuable resources - particularly intangible ones - owned by acquirers and/or targets, acquisitions lead acquirers to create value for their shareholders. Uhlenbruck et al. (2006) analyzed acquisition events of internet companies and observed value creation for acquirers whether they were from the same industry or not. This result suggests that the resources of the target should be relevant for the acquirers. Capron and Pistre (2002), on the other hand, analyzing horizontal acquisitions in several different industries, observed that acquirers should create value only if they have valuable resources that could be transferred to targets. A s we can see, there is still no consensus as to the value creation patterns regarding acquisitions events. A nalyzing acquisition events by Brazilian companies from 1994 through 2004, Patrocínio et al. (2007) also found evidence of value creation in intangibleintensive acquirers. A rguing that these valuable resources play an important role in acquisition performance, these studies extend previous evidence (e.g., B rito et al., 2005, Camargos \& Barbosa, 2007; Franks \& Harris, 1989; M orck, Shleifer, \& Vishny, 1990) that on average show no value creation for acquirers.

There is also evidence of value creation in joint ventures shown by M cConnell and Nantell (1985), W oolridge and Snow (1990), K oh and V enkatraman (1991), Das et al. (1998), Reuer and K oza (2000), and Oliveira, Kayo and Barros (2008). M cConnell and Nantell (1985) observed positive returns for companies that promoted joint ventures from 1972 through 1979. In this study, smaller companies presented higher average returns when compared to bigger companies. K oh and V enkatraman (1991) analyzed joint ventures that took place in the information technology industry and also showed evidence of a partner's value creation. Moreover, they also observed that joint ventures provided higher returns than other kinds of contractual alliances such as licensing agreements, technology exchange, etc. These results were similar to those of Woolridge and Snow (1990), who also found higher returns of joint ventures when compared to other alliances, including capital expenditures that would be more appropriately considered an internal growth alternative. More recently, Reuer and K oza (2000) found evidence of value creation in domestic joint ventures - that took place in USA - as well as in international ones from 1985 through 1995. This value creation was particularly higher in the presence of asymmetric information between partners, which is quite usual when they are from different industries. 
Das et al. (1998), analyzing technological and marketing alliances, found positive returns in the former and negative returns in the latter. In this case, higher value-enhancing alliances included research and development, engineering and manufacturing agreements. Value-decreasing marketing alliances, in their turn, included activities such as sales, distribution and customer service. According to Das et al. (1998), higher returns provided by technological alliances could be a signal of good news because of new product developments and, hence, higher future cash flows. On the other hand, marketing alliances would signal bad news because they were supposed to be promoted in the mature or declining stages in the product life cycles.

Generally, studies that analyze value creation in strategic alliances generally show positive returns. However, these studies analyze the results of a decision al ready taken. A nother important issue is what leads the firm to choose a particular strategy to grow? Y in and Shanley (2008) establish some possible drivers for this decision, involving scale/scope, dependence of resources, transaction costs, organizational learning, etc. Some of these streams are discussed in the following topics.

\section{The Organizational Learning Perspective of the Focal Firm}

Since we are analyzing different kinds of strategic alliances, it is important to define what the focal firm is. In acquisition events, the focal firm is the acquirer company, while its counterpart is the target company. In joint ventures or arm's-length alliances there is no acquirer or target, but rather partners. Sometimes, there are more than two firms involved in such contracts. In this case, each of the counterparts is alternately analyzed as a focal or partner firm, when there are sufficient data for this procedure.

According to Villalonga and McGahan (2005), from the organizational learning perspective, the value creation from any kind of alliance depends on the firm's know-how in developing such strategies, which is gained through its cumulated experience. Hence, the wider the firm's experience in managing a certain form of governance, the greater the likelihood of obtaining success in subsequent transactions of the same type. In this context, Barkema and Schijven (2008) define organizational learning as "the transfer of an organization's experience from one event to a subsequent one" (p. 596).

Kale and Singh (2007) suggest that one way through which a firm can obtain experience - and success - in strategic alliances is maintaining a dedicated team for this task. That team would be a separate organizational unit formed by people responsible for managing and coordinating the activities related to all strategic alliances. Thus, the specialization in this specific function would lead the firm to significant experience accumulation. A ccording to Kale and Singh (2007), this cumulative experience is related to the concept of deliberate learning proposed by Zollo and Winter (2002), in which all the relevant and necessary knowledge to develop complex organizational tasks is systematized.

A nand and $K$ hanna (2000) analyze the influence of the learning process on value creation in several types of strategic alliances. Their results, for instance, suggest that experience with joint ventures creates more value for firms than the cumulated experience in licensing contracts. Since evidence shows that learning from previous experiences is important for firms to create value, it is reasonable to assume that past successes could lead firms to repeat the same strategy. Thus, in accordance with Villalonga and McGahan (2005), the experience of firms in managing a certain type of governance mode makes them prone to choosing the same strategy type in future transactions. In this context, the first hypothesis to be tested is:

\section{Hypothesis 1 . The wider the experience of the focal firm in joint ventures, the greater will be the likelihood of choosing joint ventures again.}

In the same way, the firm's experience in acquisitions can also play the same role. Barkema and Schijven (2008) state that the learning process is especially important and difficult in the case of acquisitions because of their complex nature. This occurs because acquisitions involve several different activities, such as due diligence, negotiation, financing, integration, etc. In this context, the 
acquired experience in acquisitions can make a firm repeat the same strategy, as is established by Hypothesis 2.

\section{Hypothesis 2. The wider the experience of the focal firm in acquisitions, the greater will be the likelihood of choosing acquisitions again.}

\section{The Financial Perspective of the Focal Firm}

\section{Intangibility}

One of the dominant perspectives when it comes to explaining choices among several alliance al ternatives is Williamson's (1975) Transaction Costs Economics [TCE ]. This establishes the basis for decision between the use of the market or hierarchy. At first, transactions in the market should be more competitive and, therefore, more efficient than activities performed inside the firm. However, in the light of some market failures, the option for hierarchy could prevail. M arket failures are derived, particularly, from what Williamson (1975) calls asset specificity, uncertainty and transaction frequency. In the context of our paper, the first two dimensions are particularly important. Simply stated, specific assets are tailor-made to a specific transaction and cannot be easily deployed out of this specific relationship. Uncertainty can take several forms such as volume uncertainty or technological uncertainty, and appears when the relevant contingencies to the transaction are unexpected and impossible to be foreseen ex-ante in a contract or when performance cannot be easily verified ex-post (Geyskens, Steenkamp, \& K umar, 2006).

These two dimensions are particularly relevant regarding the intangibility of firms. The value of firms with this characteristic (i.e., high intangibility) is deeply determined by intangible assets - such as brands, patents, etc - which can be considered assets with high levels of specificity and uncertainty. In this way, as V illalonga and M cG ahan (2005) suggest, intangible assets are particularly vulnerable to expropriation by partners in arm's-length alliances, leading intangible-intensive firms to choose more integrative modes of governance, such as mergers and acquisitions. This view supports $Y$ in and Shanley's (2008) statement that the choice for the ideal kind of alliance depends on the magnitude of the necessary control over the resources. M ergers and acquisitions provide a larger control level on the resources. This control is appropriate when it is necessary to reduce the effects of uncertainty in a transaction, especially in the presence of partners' opportunism derived from market failures.

Two studies show the importance of intangibility for the choice among forms of alternative governance. Villalonga and M CGahan (2005), as well as Geyskens et al. (2006), found evidence that the larger the asset's specificity, the larger the likelihood of choosing more integrative forms of governance. In this context, we test the following hypothesis.

Hypothesis 3. The larger the intangibility of the focal firm, the larger the probability of choosing more integrative strategies, i.e., joint ventures instead of arm's-length alliances; acquisitions instead of joint ventures; acquisitions instead of arm's-length alliances and acquisitions instead of other alliances as a whole (joint ventures + arm's-length alliances).

\section{Financial Leverage}

A gency theory states that debt level can have positive as well as negative effects on the firm's value (J ensen, 1986; M cConnell \& Servaes, 1995; Stulz, 1990). The positive effects should appear when the firm is exposed to severe conflicts of interest between managers and shareholders mainly due to excessive free cash flow. When free cash flow is high, it motivates the manager's behavior to use these slack resources to his or her own advantage (e.g., consuming perquisites) or to financing investment projects with negative present value (e.g., acquiring another company only for empire building purposes) and then generating the so-called adverse selection problem. The debt, matched with an appropriate dividend policy, can be used as a disciplinary instrument since these strategies reduce the free cash flow and avoid overinvestment problems (Stulz, 1990). 
In contrast, debt can negatively affect a firm's value as it increases underinvestment problems (Stulz, 1990). In this case, in the presence of value creating investment projects - including acquisitions - it is important for the firms to have financial slack (or low debt level) in order to take advantage of these investment opportunities (O'B rien, 2003). Reinforcing this idea, Iyer and Miller (2008) present evidence that the likelihood of an acquisition increases with financial slack.

While financial slack is important to take advantage of investment opportunities that demand payments in cash, as is the case of acquisitions, the same does not necessarily apply to other kinds of alliances. Even if it is necessary to open a new company (as is the case of joint ventures), expenditures should be shared among the partners. Therefore, it is reasonable to presume that higher levels of financial slack (or smaller debt level) can lead to a higher likelihood of choosing more integrative forms of strategic alliances, as proposed by Hypothesis 4.

Hypothesis 4. The greater the financial leverage of the focal firm, the higher the probability of choosing less integrative strategies, i.e., arm's-length alliances instead of joint ventures; joint ventures instead of acquisitions; arm's-length alliances instead of acquisitions and other alliances as a whole (joint ventures + arm's-length alliances) instead of acquisitions.

\section{Systematic R isk}

In the context of the Capital A sset Pricing Model [CAPM ] - independently developed by some authors, among them Sharpe (1964) and Lintner (1965a, 1965b) - investors should be rewarded by the portion of the risk that does not disappear with the diversification of their investments. This nondiversifiable risk, called systematic risk, measures the sensibility of a firm's stock returns in relation to the returns of the market (usually taking, as the market portfolio, a stock index such as $S \&$ P500 or the Ibovespa in the case of Brazil).

Naik (1993) and Leland (2007) suggest that corporate events - such as acquisitions - cause changes in the firms' risk profile. Usually, there is a trend of increase in the systematic risk of the consolidated company, as suggested by Langetieg, Haugen and Wichern (1980). To our knowledge, there are no similar studies for joint ventures or arm's-length alliances. Since these alliances commit only a fraction of a firm's resources, we suppose that changes in systematic risk, if any, caused by less integrative forms of governance, will be lower than the changes caused by the more integrative forms. Therefore, we presume that, in order to avoid an increase in their systematic risk, focal firms would avoid acquisitions, preferring other types of alliance, which brings us to Hypothesis 5.

$H$ ypothesis 5. The greater the systematic risk of the focal firm, the greater the likelihood of choosing less integrative forms of governance.

\section{The Relationship between the Focal Firm and the Target/Partner}

A $n$ important concept in the literature of strategic alliances is the relational rent. Based on Dyer and Singh's (1998) definition, relational rent would be the above-normal returns that could not be generated by an isolated firm, but only through the partners' shared resources in an alliance. Lavie (2006) complements this idea suggesting that these rents "are extracted from relation-specific assets, knowledge-sharing routines, complementary resources, and effective governance mechanisms" ( $p$. 645). Departing from the assumption that relational rents are prone to appear when firms' resources are complementary (instead of similar) - as suggest by Dyer and Singh (1998) - Lavie (2006) states that value creation in joint ventures and arm's-length alliances will be larger when alliances involve complementary resources. For our purposes, we follow the same complementarity concept also used by Wang and Zajac (2007), which is defined as the extent to which the resources of two firms are different, although interdependent and mutually supportive. It is reasonable to suppose that the complementarity is more likely to exist among firms of different industries, since different activities can involve different resources. 
Wang and Zajac (2007) remind us that similar firms will have a higher potential to create value if they work together within the boundaries of a single firm. This happens because of the possibility of eliminating redundancies of assets and operations, leading to economies of scale and/or scope. On the other hand, when the businesses are complementary, an alliance allows a firm to benefit from the sharing of knowledge and experiences with its partners. It is important to emphasize that this benefit should be mutual, since all partners would have different knowledge and experience in their own field. This partnership would then lead to the development of new resources - impossible to achieve with the firms working apart - that could generate new sources of relational rent.

According to Balakrishnan and Koza (1993), information asymmetries play an important role in making the firm discard an acquisition and choose a joint venture instead. In this sense, joint ventures will be more appropriate than acquisitions if the costs of evaluating assets of the potential target, or partner, are excessively high because of the lack of information of each other's business environment and operations (Wang \& Zajac, 2007). This problem is more likely to appear when firms are from different industries, i.e., if they are not related. In other words, related firms, which know each other's business, will prefer to choose an acquisition and not a joint venture, which brings us to Hypothesis 6.

\section{Hypothesis 6. The larger the relatedness between the focal firm and the target/partner firm, the greater the likelihood of choosing more integrative governance modes.}

\section{METHODS}

\section{Sample and Data}

Our hypotheses test the relationship among categorical dependent variables and some independent metric and dummy variables. Two categorical variables are analyzed in several different models. B oth variables represent the different firm's growth strategies options. The first dependent variable is binary and only two growth alternatives are analyzed in each model. The second dependent variable includes, simultaneously, the three growth strategies (acquisitions, joint ventures and arm's-length alliances). Because of the categorical nature of dependent variables, we applied probit and ordered probit analyses.

W e performed probit analysis for the models that use the binary dependent variable. We alternately compared (1) arm's-length alliances against joint ventures, (2) joint ventures against acquisition, (3) arm's-length alliances against acquisitions and (4) alliances - joint ventures and arm's-length alliances - against acquisitions. A dditionally, ordered probit makes it possible to analyze a dependent variable with an ordinal scale. Therefore, we performed this model to analyze the determinants of the choice among arm's-length alliances, joint ventures or acquisitions.

It is important to highlight that the analysis using a probit model follows the study of Villalonga and M CGahan (2005), which investigates the choice among acquisitions, alliances and divestitures. Other techniques for analyzing categorical data could be applied as, for instance, logit models. Thus, instead of using normal distribution in a probit model, we could use a logistic distribution in a logit model.

But, as Greene (2003, p. 667) suggests "it is difficult to justify the choice of one distribution or another on theoretical grounds" and "in most applications, the choice between these two seems not to make much difference". Indeed, considering probit and logit transforms as links functions, Gill (2001, p. 33) establishes that "in general, with social science data any of these link functions can be used and will provide identical substantive conclusions". Thus, it is expected that the main results with the use of a logistic regression model would not differ from the results described in this work.

The sample of the research includes growth strategy events announced by Brazilian public companies from 1996 through 2007. These kinds of events are necessarily reported from firms to the 
Comissão de Valores Mobiliários [CVM] - which is the equivalent to the Securities Exchange Commission [SEC] - in the USA. We gathered financial data from the Economatica database, which is similar, for instance, to the familiar Compustat database.

Initially, we collected 460 growth event announcements: 294 acquisitions, 81 joint ventures and 85 arm's-length alliances. The final number of cases analyzed in each model depended mainly on the availability of financial data. This amount varied from 162 observations in the probit model that analyzed the choice between arm's-length alliances and joint ventures to 346 observations, in the ordered probit model.

\section{Variables}

\section{Dependent Variables}

Our dependent variables represent three growth options: acquisitions, joint ventures and arm'slength alliances. Simply stated, for our probit and ordered probit models, larger values on the scale of the dependent variable indicate strategies of higher integration. In this way, acquisitions take the highest values, whereas joint ventures have smaller values compared to acquisitions. A rm's-length alliances, which are less integrative, take the smallest values on the scale of the dependent variable. In this last category, we included, for instance, commercial agreements, licensing contracts, partnerships in production, etc. For example, we classified in this category commercial agreements such as those that were accomplished between the Brazilian airline company $\mathrm{Gol}$ and other companies of the same industry, such as Delta Airlines and A erolineas Argentinas. The agreement among these companies aimed to enhance airplane occupation with conjoint ticket sales.

Identification of events regarding acquisitions and joint ventures are straightforward. A cquisition events were included in the sample if the acquirer's final total amount of the target's ownership were higher than $50 \%$. We included an acquisition event whatever the payment method, through cash or stock. Finally, events in which two or more firms agreed to create a new organization for the development or commercialization of some specific product or service were classified as joint ventures. For instance, several agreements between Brazilian banks and retail firms resulting in the formation of a new consumer finance company were classified as joint ventures.

As anticipated in the previous topic, we alternately analyzed two dependent variables, both categorical. The first dependent variable confronts two kinds of growth strategy in each model. In M odel 1, the dependent variable takes the value 1 if the growth strategy is joint venture and the value zero if it is arm's-length. In M odel 2, acquisitions take the value 1 while joint ventures take the value zero. In M odel 3, the value 1 again represents the strategy of acquisitions and the value zero is for arm's-length alliances. Finally, in M odel 4, acquisitions take the value 1 and alliances - the totality of joint ventures and arm's-length alliances - take the value 0.

The second dependent variable simultaneously confronts all three growth strategies. In this case, the dependent variable has a scale with three categories. A gain, following the criterion of larger values for more integrative strategies, the value 0 is attributed to arm's-length alliances, the value 1 to joint ventures and the value 2 to acquisitions.

\section{Independent Variables}

Independent variables are divided into families: (1) organizational learning variables regarding the focal firm, (2) financial variables also regarding the focal firm and (3) a variable regarding the relatedness between the focal firm and the target/partner firm.

The first group includes two variables: experience in joint ventures and experience in acquisitions. The variable experience in joint ventures, which tests Hypothesis 1 , is measured as the yearly average amount of transactions accomplished in the period of 12 years of analysis (1996 to 2007). If, for 
instance, a company took part in 6 joint venture deals during this period, its index will be of 0.5 (i.e., $6 / 12$ ). The same criterion is applied for experience in acquisitions, which tests Hypothesis 2 . The idea of these variables is that the higher the ratio, the larger the acquired experience for the focal firm. These variables are similar to those proposed by Villalonga and M CGahan (2005).

The second group of variables, regarding some focal firms' financial characteristics, has three variables: intangibility, financial leverage and systematic risk. Intangibility, which tests Hypothesis 3 , is measured by Tobin's q, a proxy also used by Villalonga (2004) when analyzing the influence of intangibility on a firm's superior performance. Originally, Tobin's $q$ is defined as the ratio between the firm's total market value - including equity and debt - to the replacement cost of the firm's assets. Chung and Pruitt (1994) suggest a simplified version of Tobin's q, substituting the value of replacement costs for the value of total assets. In spite of this simplification, the authors demonstrate that their version is capable of explaining $96.6 \%$ of the variance of $q$ in its original form. Thus, we decided to adopt this simplified version. The variable financial leverage, which tests Hypothesis 4 , is measured by the ratio of long term debt to the firm's market value. The variable systematic risk, which tests hypothesis 5 , is measured by the so-called CAPM 's beta. The beta is a measure of the firm's nondiversifiable risk or, in other words, a measure of the firm's return sensibility in relation to the market return. The larger the beta, the larger the level of the firm's systematic risk. In our paper, the beta is measured by the covariance between firm's stock and market return - on a monthly basis - divided by the variance of monthly market returns. We used the Ibovespa - one of the Brazilian stock indexes as a proxy for market returns.

Finally, the relatedness variable is a dummy variable that takes the value 1 if the target/partner firm belongs to the same industry of the focal firm and 0 otherwise. Our parameter for this measurement was the simplified industry classification of the Economatica database.

\section{RESULTS}

\section{Probit Analysis}

Table 1 shows the results of probit analysis, in which, as described earlier, the two categories to be analyzed represent different growth strategies: a more integrative with value 1 and a less integrative strategy with value 0 . The value of the Log likelihood of the fitted model is used in the Likelihood Ratio [LR ] Chi-Squared test and indicates that M odels 2, 3 and 4 were significant at a $1 \%$ significance level and Model 1 at $2 \%$. LR Chi-Squared tests the hypothesis that at least one of the regression coefficients is other than zero. Thus, in all the models, we expected to obtain at least one predictor variable explaining the choice of growth strategy.

The pseudo $R^{2}$ values in Table 1 are based on a measure suggested by M CFadden (1973) and indicate, in M odels 2, 3 and 4, that the variability of independent variables may explain a significant part of the variance of the dependent variable. Thus, the higher the Pseudo $R^{2}$, the better the model. For instance, M odel 2 presents an index of approximately $47 \%$ whereas M odel 1 has a Pseudo $R^{2}$ of only $6 \%$. It is important to emphasize that the nature of the dependent variable in a probit or ordered probit analysis prevents the estimation of a number which represents the exact concept of the coefficient of determination $\mathrm{R}^{2}$ in an OLS (ordinary least squares) regression context. Nevertheless, although Pseudo $R^{2}$ measures do not exactly mean explained variance, they can be used to analyze goodness-of-fit of models.

Corroborating Hypotheses 1 and 2, the focal firms' cumulated experience in developing certain expansion strategies lead them to a higher likelihood of adopting the same strategy type in other transactions. In other words, firms with experience in acquisitions are more likely to choose 
acquisitions again as a growth strategy and firms with experience in joint ventures are more likely to choose joint ventures.

M odel 1 analyzes the determinants of choosing between arm's-length al liances or joint ventures. The positive and significant sign of the coefficient for experience in joint ventures $(\beta=.68 ; p<0.01)$ indicates that the wider a firm's experience in joint ventures, the greater the likelihood to choose joint ventures again. The variable experience in acquisitions was not included in this model because it was not being analyzed - the dependent variable is related to arm's-length alliances or joint ventures. Model 2, in its turn, confronts joint ventures against acquisitions, and includes the two variables related to experience in each strategy type. As expected, the experience in joint ventures leads to a greater likelihood to choose joint ventures $(\beta=-4.62 ; p<.01)$ and experience in acquisitions leads to other acquisitions $(\beta=2.64 ; p<.01)$. Model 3 tests two extreme strategies: acquisitions - more integrative strategy - and arm's-length alliances - less integrative strategy. A gain, as expected, the experience in acquisitions shows a positive and significant coefficient $(\beta=1.74 ; p<.01)$. Finally, M odel 4 analyzes the decision between acquisitions or alliances as a whole, i.e., all events regarding joint ventures and arm's-length alliances. In this case, the same results persist, indicating an association between the experience in a given strategy and the choice of the same type of deal.

Table 1

\section{Results of Probit Analysis}

\begin{tabular}{|c|c|c|c|c|}
\hline V ariables & $\begin{array}{c}\text { Model } 1 \\
\text { Arm's x JV }\end{array}$ & $\begin{array}{c}\text { M odel } 2 \\
\text { JV x AQUIS. }\end{array}$ & $\begin{array}{c}\text { Model } 3 \\
\text { Arm's x A quis. }\end{array}$ & $\begin{array}{c}\text { M odel } 4 \\
\text { Alliances } x \text { A quis }\end{array}$ \\
\hline Intercept & -0.05 & $-1.17 * * *$ & $-1.26 * * *$ & $-1.72 * * *$ \\
\hline \multicolumn{5}{|l|}{ Focal firm (learning perspective) } \\
\hline Experience in joint ventures & $0.68 * * *$ & $-4.62 * * *$ & & $-3.65 * * *$ \\
\hline Experience in acquisitions & & $2.64 * * *$ & $1.74 * * *$ & $2.50 * * *$ \\
\hline \multicolumn{5}{|c|}{ Focal firm (financial perspective) } \\
\hline Intangibility & 0.03 & 0.01 & 0.04 & 0.02 \\
\hline Financial leverage & 0.14 & 0.14 & 0.09 & 0.08 \\
\hline Systematic risk & -0.41 & -0.04 & $-0.37 *$ & -0.10 \\
\hline \multicolumn{5}{|l|}{ Focal and target/partner firms } \\
\hline Relatedness & -0.22 & $1.82 * * *$ & $1.44 * * *$ & $1.79 * * *$ \\
\hline Number of observations & 162 & 263 & 267 & 346 \\
\hline Log likelihood & 13.36 & 149.80 & 90.71 & 192.18 \\
\hline Prob. $>\cdot^{2}$ & 0.0202 & 0.0000 & 0.0000 & 0.0000 \\
\hline Pseudo $\mathrm{R}^{2}$ & 0.06 & 0.47 & 0.27 & 0.40 \\
\hline
\end{tabular}

Note. ${ }^{*} p<.10 ; * * p<.05 ; * * * p<.01$

If, on the one hand, all the variables related to the focal firm's learning were significant to explain the choice of the growth strategy, on the other hand, the financial variables did not show statistical significance. The only exception was due to the systematic risk variable which, in Model 3 , has a negative and significant sign $(\beta=-0.37 ; p<0,10)$, as expected, indicating that riskier focal firms choose less integrative options to grow. The results showed that intangibility and the financial leverage of the focal firm are not relevant for the choice of the growth strategy. 
Finally, as expected, the relatedness was statistically significant to explain the choice of growth mode. Except for M odel 1, the results suggest that when companies are from the same industry, there is a greater likelihood of their choosing more integrative growth options.

\section{Ordered Probit Analysis}

Since the probit analysis allows a comparison between only two categories at a time, we also investigated the choice of growth strategy using a richer ordinal scale based on the level of integration of growth strategies among companies. In this context, Table 2 displays the results of the ordered probit analysis in which all growth strategies are analyzed simultaneously. The dependent variable is ordinal and, as explained in the methods topic, the value zero is attributed to the arm's-length alliances, the value 1 to joint ventures and the value 2 to acquisitions. Given the construction of this scale, a positive sign of the coefficients indicates a greater likelihood of choosing more integrative strategies. A negative sign indicates the opposite, i.e., a greater likelihood of choosing less integrative strategies.

Table 2

\section{Results of Ordered Probit Analysis}

\begin{tabular}{|c|c|}
\hline V ariable & $\begin{array}{c}\text { Model } 5 \\
\text { Arm's } \times \text { JV } \times \text { Aquis. }\end{array}$ \\
\hline \multicolumn{2}{|l|}{ Focal firm (learning perspective) } \\
\hline Experience in joint ventures & $-0.67 * * *$ \\
\hline Experience in acquisitions & $1.13^{* * *}$ \\
\hline \multicolumn{2}{|c|}{ Focal firm (financial perspective) } \\
\hline Intangibility & 0.03 \\
\hline Financial leverage & 0.07 \\
\hline Systematic risk & -0.05 \\
\hline \multicolumn{2}{|l|}{ Focal and target/partner firms } \\
\hline Relatedness & $1.20 * * *$ \\
\hline Number of observations & 346 \\
\hline Log likelihood & 120.44 \\
\hline Prob. $>\bullet^{2}$ & 0.0000 \\
\hline Pseudo $R^{2}$ & 0.17 \\
\hline
\end{tabular}

Note. $* p<.10 ; * * p<.05 ; * * * p<.01$

The results of ordered probit analysis, in general, corroborate the results with binary probit. Log likelihood of fitted models and the related $\mathrm{Chi}$-squared test show that at least one independent variable is important to explain the choice of growth strategy in a situation among three alternatives taken simultaneously. The variable of focal firms' experience in joint ventures is negative and statistically significant $(\beta=-0.67 ; p<0.01)$, indicating the tendency to choose less integrative forms of growth. The coefficient sign of experience in acquisition, on the other hand, is positive and significant ( $\beta=$ 1.13; $p<0.01$ ), indicating that firms would choose acquisitions. The financial variables - intangibility, financial leverage and systematic risk - again did not show statistical significance. The relatedness, however, confirmed our hypothesis and shows a positive relationship, i.e., that similar firms will prefer more integrative forms of governance. 


\section{DISCUSSION AND CONCLUDING REMARKS}

The objective of this article was to analyze the determinants of the choice among different strategies of firm's external growth: acquisitions, joint ventures or arm's-length alliances. The results corroborate previous studies from other countries in respect to the importance of the organizational learning process in the choice of the most appropriate strategic alliance. It is also confirmed the hypothesis that similar (i.e., related) - companies prefer acquisitions instead of less integrative types of alliances, particularly because of economies of scale and scope. In contrast, less related companies would prefer to celebrate less integrative alliances in specific business segments, since their resources are complementary and provide them with a relational rent that could not possibly be generated in separate firms. In this last case, the lack of similarity among the resources of those companies would not justify total agglomeration through mergers or acquisitions.

Our results confirm three out of six tested hypotheses. As expected, the variables related to the organizational learning perspective were significant to explain the choice of the most appropriate growth strategy. It suggests that the firms' cumulated experience in a given strategic alliance type is relevant for them to choose the same strategy type in future transactions. A nother confirmed result is the positive relationship between relatedness and the choice for more integrative forms of alliance. The theory suggests that companies belonging to the same industry tend to have similar information, implying that they know each other very well. In this environment of informational symmetry, there would be a higher potential for value creation if the focal firm chooses acquisition. In contrast, if companies do not work in the same industry, the value creation would rely on the complementarity of some few resources of the partners and not on the totality of the firms' resources.

The lack of significance of the financial variables ought to be analyzed with caution. Regarding the financial leverage, for instance, our initial assumption was that acquisition would be more easily accomplished if the acquirer were to have financial slack (i.e., low levels of debt). However, one must considerer that the method of payment can play an important role in acquisition events. It is important to bear in mind that acquiring firms may make the payment in cash or stocks. In this way, if an acquisition were made through stock as a method of payment, financial slack would be irrelevant. We suggest that this factor be controlled in future studies. Unfortunately, in the Brazilian sample, including the variable of method of payment would excessively reduce our sample.

There is another important issue concerning systematic risk. It was expected that the focal firm would choose less integrative forms of growth in order to avoid an increase in systematic risk, which could take place in the case of an acquisition. However, although some studies (e.g., Langetieg et al., 1980) show an increase in the firm's systematic risk derived from an acquisition, there are empirical controversies. As Seth (1990) reminds us, other studies by Haugen and Langetieg (1975) and Firth (1978) show no significant changes in systematic risk after acquisitions. If this is the case, the systematic risk should not make any difference in the decision making for a specific growth option.

Although the two financial variables have not been statistically significant, we believe that the theoretical arguments are sufficiently convincing for future studies to take these factors into account. A nother suggestion for future studies is the inclusion of other types of growth strategies as well as decrease strategies, such as divestitures (e.g., V illalonga \& M cGahan, 2005 also analyzed this last type of strategy). It is important to emphasize that decisions involving the contraction of the firm's boundaries are as important as expansion decisions. In fact, in times of crisis, divestitures can be an important survival strategy.

By empirically analyzing the possible determinants of choice among acquisitions, joint ventures or arm's-length alliances, studies such as ours can help firms to build corporate investment policies aligned with the best interests of shareholders, i.e., value creation. In this context, analyzing how the uniqueness of each firm affects their choices of growth strategies can be crucial for firms to understand the differences between simply growing or growing creating value. 
Thus, we hope to make a contribution to the strategy literature as well as to the practitioners. The main theoretical contribution of our study relies on the discussion of the role that some firm financial characteristics (i.e., intangibility, financial leverage and systematic risk) play in the choice of the growth strategy. A s suggested by $Y$ ang, Lin and Lin (2010), a comprehensive framework is critical for disentangling the factors affecting the choice among different types of alliances. In this context, we state that a financial perspective may have the potential to add important elements to the understanding of a firm's boundaries. In addition, we hope that managers benefit from this discussion since it addresses the role of the firm's characteristics as well as dyadic similarities and differences concerning the most appropriate strategic choice for sustainable growth.

\section{REFERENCES}

A nand, B. N., \& K hanna, T. (2000). D o firms learn to create value? The case of alliances. Strategic M anagement J ournal, 21(3), 295-315.

Balakrishnan, S., \& K oza, M . (1993). Information asymmetry, adverse selection, and joint ventures. J ournal of Economic Behavior and Organization, 20(1), 99-117.

Barkema, H. G., \& Schijven, M. (2008). How do firms learn to make acquisitions? A review of past research and an agenda for the future. J ournal of M anagement, 34(3), 594-634.

B rito, G. A. S., Batistella, F. D., \& Famá, R. (2005). Fusões e aquisições no setor bancário: avaliação empírica do ef eito sobre o valor das ações. Revista de Administração da U SP , 40(4), 353-360.

Camargos, M. A., \& Barbosa, F. V. (2007). A nálise empírica da reação do mercado de capitais brasileiro aos anúncios de fusões e aquisições ocorridos entre 1994 e 2001. Revista de Administração da U SP, 42(4), 468-481.

Capron, L., \& Pistre, N. (2002). When do acquirers earn abnormal returns? Strategic Management J ournal, 23(9), 781-794.

Chung, K . H., \& Pruitt, S. W . (1994). A simple approximation of Tobin's Q. Financial Management, 23(3), 70-74.

Das, S., Sen, P. K., \& Sengupta, S. (1998). Impact of strategic alliances on firm valuation. Academy of M anagement J ournal, 41(1), 27-41.

Dyer, J. H., \& Singh, H. (1998). The relational view: cooperative strategy and sources of interorganizational competitive advantage. Academy of M anagement Review, 23(4), 660-679.

Firth, M . (1978). Synergism in mergers: some B ritish results. The J ournal of F inance, 33(2), 670-672.

Franks, J. R., \& Harris, R. S. (1989). Shareholder wealth effects of corporate takeovers: the U.K. experience 1955-1985. J ournal of F inancial Economics, 23(2), 225-250.

Geyskens, I., Steenkamp, J. B. E. M., \& Kumar, N. (2006). Make, buy, or ally: a transaction cost theory meta-analysis. Academy of M anagement J ournal, 49(3), 519-543.

Gill, J. (2001). Generalized linear models: a unified approach. California: Sage Publications.

Greene, W. H. (2003). E conometric analysis (5th ed.). N ew J ersey: Prentice Hall.

Haugen, R. A ., \& Langetieg, T. C. (1975). An empirical test for synergism in merger. The J ournal of Finance, 30(4), 1003-1014. 
Hennart, J. F . (1993). Explaining the swollen middle: why most transactions are a mix of "market" and "hierarchy". Organization Science, 4(4), 529-547.

Iyer, D. N, \& Miller, K. D. (2008). Performance feedback, slack, and the timing of acquisitions. Academy of M anagement J ournal, 51(4), 808-822.

Jensen, M. C. (1986). A gency costs of free cash flow, corporate finance and takeovers. American E conomic Review, 76(2), 323-329.

Kale, P., \& Singh, H. (2007). Building firm capabilities through learning: the role of the alliance learning process in alliance capability and firm-level alliance success. Strategic Management J ournal, 28(10), 981-1000.

Kogut, B. (1988). Joint ventures: theoretical and empirical perspectives. Strategic Management J ournal, 9(4), 319-332.

Koh, J., \& Venkatraman, N. (1991). Joint venture formations and stock market reactions: an assessment in the information technology sector. Academy of Management J ournal, 34(4), 869892.

Langetieg, T. C., Haugen, R. A., \& Wichern, D. W. (1980). M erger and stockholder risk. J ournal of Financial and Quantitative Analysis, 15(3), 689-717.

Lavie, D. (2006). The competitive advantage of interconnected firms: an extension of the resourcebased view. Academy of M anagement Review, 31(3), 638-658.

Leland, H. E. (2007). Financial synergies and the optimal scope of the firm: implications for mergers, spinoffs, and structured finance. The J ournal of Finance, 62(2), 765-807.

Lintner, J. (1965a). The valuation of risk assets and the selection of risky investments in stock portfolios and capital budgets. The Review of Economics and Statistics, 47(1), 13-37.

Lintner, J. (1965b). Security prices, risk, and maximal gains from diversification. The J ournal of Finance, 20(4), 587-615.

Makadok, R. (2001). Toward a synthesis of the resource-based and dynamic-capability views of rent creation. Strategic M anagement J ournal, 22(5), 387-401.

M cConnell, J . J., \& Nantell, T. (1985). Corporate combinations and common stock returns: the case of joint ventures. The J ournal of F inance, 40(2), 519-536.

McConnell, J. J., \& Servaes, H. (1995). Equity ownership and the two faces of debt. Journal of Financial Economics, 39(1), 131-157.

M cFadden, D. (1973). Conditional logit analysis of qualitative choice behavior. In P. Zarembka (Ed.), F rontiers in E conometrics (pp. 105-142). N ew Y ork: A cademic Press.

Morck, R., Shleifer, A., \& Vishny, R. W. (1990). Do managerial objectives drive bad acquisitions? The J ournal of Finance, 45(1), 31-48.

Naik, V . (1993). O ption valuation and hedging strategies with jumps in the volatility of asset returns. The J ournal of Finance, 48(5), 1969-1984.

O'B rien, J. P. (2003). The capital structure implications of pursuing a strategy of innovation. Strategic M anagement J ournal, 24(5), 415-431. 
Oliveira, L. E., Neto, K ayo, E. K., \& Barros, L. A. B. C. (2008). A formação de alianças estratégicas no Brasil e a criação de valor para as empresas participantes: um estudo de evento. Revista de Administração - eletrônica, 1(2), 1-21. Retrieved December 26, 2008, from http://www.rausp.usp.br/R evista_el etronica/v1n2

Patrocínio, M . R., K ayo, E. K., \& K imura, H. (2007). A quisição de empresas, intangibilidade e criação de valor: um estudo de evento. Revista de Administração U SP , 42(2), 205-215.

Penrose, E. (1959). The theory of the growth of the firm. Oxford: Oxford University Press.

Peteraf, M. (1993). The cornerstones of competitive advantage: a resource-based view. Strategic M anagement J ournal, 14(3), 179-191.

Reuer, J., \& K oza, M. (2000). A symmetric information and joint venture performance: theory and evidence for domestic and international joint ventures. Strategic M anagement J ournal, 21(1), 81-88.

Sawler, J. (2005). Horizontal alliances and the merger paradox. M anagerial and Decision Economics, 26(4), 243-248.

Seth, A. (1990). Sources of value creation in acquisitions: an empirical investigation. Strategic M anagement J ournal, 11(6), 431-446.

Sharpe, W. F. (1964). Capital asset prices: a theory of market equilibrium under conditions of risk. The J ournal of F inance, 19(3), 425-442.

Stulz, R. (1990). Managerial discretion and optimal financing policies. Journal of Financial Economics, 26(1), 3-27.

Teece, D. J. (1992). Competition, cooperation, and innovation: organizational arrangements for regimes of rapid technological progress. Journal of Economic Behavior and Organization, $18(1), 1-25$.

Uhlenbruck, K., Hitt, M. A., \& Semadeni, M . (2006). M arket value effects of acquisitions involving internet firms: a resource-based analysis. Strategic M anagement J ournal, 27(10), 899-913.

Villalonga, B. (2004). Intangible resources, Tobin's q, and sustainability of performance differences. J ournal of Economic Behavior \& Organization, 54(2), 205-230.

Villalonga, B ., \& M cGaham, A. M . (2005). The choice among acquisitions, alliances, and divestitures. Strategic M anagement J ournal, 26(1), 1183-1208.

Wang, L., \& Zajac, E. J. (2007). Alliance or acquisition? A dyadic perspective on interfirm resource combinations. Strategic M anagement J ournal, 28(13), 1291-1317.

Williamson, O. E. (1975). Markets and hierarchies: analysis and antitrust implications. New York: Free Press.

Williamson, O. E. (1991). Comparative economic organization: the analysis of discrete structural al ternatives. Administrative Science Q uarterly, 36(2), 269-296.

Woolridge, J. R., \& Snow, C. C. (1990). Stock market reaction to strategic investment decisions. Strategic M anagement J ournal, 11(5), 353-363.

Y ang, H., Lin, Z., \& Lin, Y . (2010). A multilevel framework of firm boundaries: firm characteristics, dyadic differences, and network attributes. Strategic M anagement J ournal, 31(3), 237-261. 
Y in, $X$., \& Shanley, M. (2008). Industry determinants of the "merger versus alliance" decision. Academy of M anagement Review, 33(2), 473-491.

Zollo, M., \& Winter, S. G. (2002). Deliberate learning and the evolution of dynamic capabilities. Organization Science, 13(3), 339-351. 